\title{
Mutations in WT1 in boys with sporadic isolated steroid-resistant nephrotic syndrome
}

\author{
Y. Yang ${ }^{1,2,3 *}$, F. Zhao ${ }^{1,2,3 *}, \mathrm{X} . \mathrm{Tu}^{4}$ and Z. Yu ${ }^{1,2,3}$ \\ ${ }^{1}$ Department of Pediatrics, Fuzhou Dongfang Hospital, Fuzhou, Fujian, China \\ ${ }^{2}$ Department of Pediatrics, Fuzhou Clinical Medical College, Fujian Medical University, \\ Fuzhou, Fujian, China \\ ${ }^{3}$ Department of Pediatrics, Affiliated Dongfang Hospital, Xiamen University, \\ Fuzhou Fujian, China \\ ${ }^{4}$ Research Center for Molecular Diagnosis of Genetic Diseases, \\ Fuzhou Dongfang Hospital, Fuzhou, Fujian, China \\ *These authors contributed equally to this study. \\ Corresponding author: Z. Yu \\ E-mail: zihuayu@vip.sina.com
}

Genet. Mol. Res. 15 (1): gmr.15017559

Received September 1, 2015

Accepted November 17, 2015

Published March 11, 2016

DOI http://dx.doi.org/10.4238/gmr.15017559

\begin{abstract}
Mutations in the Wilms' tumor gene, WT1, can lead to syndromic steroid-resistant nephrotic syndrome and isolated steroidresistant nephrotic syndrome. WT1 mutations have been identified in the majority of children with Denys-Drash or Frasier syndrome. WT1 mutations have not previously been identified in boys with sporadic isolated steroidresistant nephrotic syndrome, but, recently, four boys with isolated nephrotic syndrome were identified to have WT1 mutations. However, whether boys with sporadic isolated steroid-resistant nephrotic syndrome should be routinely subjected to mutation analysis of WT1 has not been established. We examined 35 boys with sporadic isolated steroid-resistant nephrotic syndrome for mutations in WT1. Mutation analysis of all 10 exons of WT1 was performed by polymerase chain reaction and direct sequencing. Karyotype analysis or $Y$ chromosome identification was performed for all patients. A Y chromosome or a 46, XY karyotype was demonstrated for
\end{abstract}


all 35 patients. No causative WT1 mutation was identified in any of the patients. The WT1 mutation, IVS4+14T>C, which is not predicted to affect splicing, was identified in one patient who achieved complete remission after 8 weeks of oral prednisone treatment, indicating that IVS4+14T>C is not a causative mutation. Five WT1 polymorphisms were also identified in some patients and controls. Our results suggest that mutation analysis of WT1 should not be routinely performed for genetically defined boys with sporadic isolated steroid-resistant nephrotic syndrome.

Key words: Male; Mutation; Polymerase chain reaction; WT1; Steroid-resistant nephrotic syndrome

\section{INTRODUCTION}

Idiopathic nephrotic syndrome (INS) is characterized by proteinuria, hypoalbuminemia, hyperlipidemia, and edema and is the most common childhood glomerular disease (Yu et al., 2005). INS is divided into steroid-sensitive nephrotic syndrome and steroid-resistant nephrotic syndrome (SRNS) based on the patient's response to steroid treatment. Most children with sporadic INS respond to steroids and have a favorable long-term prognosis; however, $10-20 \%$ of patients do not respond to steroids and may progress to end-stage renal disease (ESRD) (Weber et al., 2004; Ruf et al., 2004a). Mutations in genes encoding podocyte proteins such as NPHS1 (OMIM 256300), NPHS2 (OMIM 604766), CD2AP (OMIM 607607832), and the Wilms' tumor gene, WT1 (OMIM 607102), are responsible for SRNS in children (Weber et al., 2004; Mucha et al., 2006; Löwik et al., 2007; Philippe et al., 2008).

The WT1 gene, located on chromosome $11 \mathrm{p} 13$ and consisting of 10 exons, plays a crucial role in kidney and genital system development (Call et al., 1990; Haber et al., 1991; Bruening et al., 1992). Mutations in WT1 can lead to syndromic forms of SRNS, such as Denys-Drash syndrome (OMIM 194080) and Frasier syndrome (OMIM 136680), and can cause isolated SRNS (Pelletier et al., 1991; Barbaux et al., 1997; Mucha et al., 2006). Denys-Drash syndrome is characterized by the triad of infantile SRNS, ambiguous genitalia, and Wilms' tumor (Chernin et al., 2010). Frasier syndrome is characterized by the association of SRNS with male pseudohermaphroditism (Chernin et al., 2010). Isolated SRNS discussed here refers to SRNS without accompanying genital abnormalities, Wilms' tumor, ocular abnormalities, audiological abnormalities, or mental retardation.

WT1 mutations have been identified in the majority of children with Denys-Drash syndrome or Frasier syndrome (Niaudet and Gubler, 2006). A WT1 mutation is also a frequent cause of sporadic isolated SRNS in girls, occurring in $10.8 \%$ of girls in a worldwide cohort (Muchaet al., 2006). No WT1 mutations have been detected in boys with sporadic isolated SRNS (Ruf et al., 2004b; Aucella et al., 2006; Mucha et al., 2006; Cho et al., 2008; Li et al., 2010). Our previous study identified no mutations in exons 8 and 9 of WT1 in 38 boys with sporadic isolated SRNS (Yang et al., 2013b). However, WT1 mutations in sporadic isolated SRNS children may occur in exons other than 8 and 9 (Takata et al., 2000), and recently four boys with isolated nephrotic syndrome were identified to have WT1 mutations (Takata et al. 2000; Tajima et al. 2003; Chernin et al. 2010; Yang et al. 2013a). There is currently no guideline regarding whether boys with sporadic isolated SRNS 
should be routinely subjected to $W T 1$ mutation analysis. This study aims to examine mutations in all 10 exons of WT1 in 35 boys with sporadic isolated SRNS using polymerase chain reaction (PCR) and direct sequencing.

\section{MATERIAL AND METHODS}

\section{Subjects}

We enrolled 35 boys based on the following inclusion criteria: 1) no family history of renal diseases and not born from consanguineous parents; 2) older than 3 months and younger than 18 years at disease onset; 3) diagnosed with SRNS; 4) absence of Wilms' tumor based on renal ultrasound; 5) audiometry showed a lack of symmetrical deficits for high-frequency sounds; 6) ophthalmologic assessment confirmed a lack of ocular lesions; 7) clinical and laboratory examinations demonstrated a lack of post-infectious glomerulonephritis and systemic diseases; 8) not mentally retarded; and 9) had no NPHS2 mutations. Nephrotic syndrome was diagnosed based on 24-h urinary protein excretion greater than $0.05 \mathrm{~g} / \mathrm{kg}$, with serum albumin less than $25 \mathrm{~g} / \mathrm{L}$. Steroid resistance was defined as the absence of remission after an initial four weeks of steroid therapy at a dose of $2 \mathrm{mg} \cdot \mathrm{kg}^{-1} \cdot \mathrm{day}^{-1}$. As control subjects, we also studied 100 unrelated adult volunteers with normal urinalyses. This study was approved by the Ethics Committee of Fuzhou Dongfang Hospital (China) and was performed in accordance with the Declaration of Helsinki. Informed consent was obtained from patients' parents and control subjects.

\section{Karyotype analysis or Y chromosome identification}

To confirm the gender of patients, karyotype analysis was performed on five patients. For the other 30 patients, the sex-determining region $Y$ gene, SRY (a specific marker for the $Y$ chromosome), was identified by PCR amplification (Harley et al., 2003). The SRY primers used were described previously (Tu et al., 2008).

\section{WT1 mutation analysis}

For genetic analysis of WT1, genomic DNA was isolated from peripheral blood. All 10 exons of WT1 were amplified from genomic DNA by PCR. Genomic DNA (50 ng) was subjected to PCR amplification in a $25-\mu \mathrm{L}$ volume consisting of $1 \mu \mathrm{L} 5 \mu \mathrm{M}$ sense primer, $1 \mu \mathrm{L} 5 \mu \mathrm{M}$ antisense primer, 1.5-3.5 $\mu \mathrm{L} 25 \mathrm{mM} \mathrm{MgCl}_{2}, 1 \mu \mathrm{L} 2.5 \mathrm{mM}$ deoxyribonucleotide triphosphates, and $0.125 \mu \mathrm{L} 5 \mathrm{U} / \mu \mathrm{L}$ Taq polymerase (Promega Corporation, Madison, WI, USA). The PCR conditions were as follows: $94^{\circ} \mathrm{C}$ for $7 \mathrm{~min}$, followed by 36 cycles of $94^{\circ} \mathrm{C}$ for $30 \mathrm{~s}, 56^{\circ}-64^{\circ} \mathrm{C}$ for $30 \mathrm{~s}$, and $72^{\circ} \mathrm{C}$ for $1 \mathrm{~min}$, followed by $72^{\circ} \mathrm{C}$ for $7 \mathrm{~min}$. Because of the high $\mathrm{GC}$ content of exon $1,2 \mathrm{X}$ GC buffer I and LA polymerase (Takara, Shiga, Japan) was added to the reaction mixture. The PCR products were visualized using $1.5 \%$ agarose $(\mathrm{w} / \mathrm{v})$ gel electrophoresis. PCR amplicons were directly sequenced using an ABI 3730XL DNA Analyzer (Shanghai Invitrogen Biotechnology, Shanghai, China). Mutations were confirmed by sequencing in both directions and by repeated amplification and sequencing. 


\section{Splice site predictions}

We used programs hosted by the NetGene2 Server (http://www.cbs.dtu.dk/services/NetGene2/) and the Berkley Drosophila Genome Project (http://www.fruitfly.org/seq_tools/splice.html) to predict splice sites in WT1.

\section{RESULTS}

\section{Clinical data}

The 35 boys with sporadic isolated SRNS did not have genital abnormalities, Wilms' tumor, ocular abnormalities, hearing abnormalities, or mental retardation (Table 1). Their age at onset was $4.3 \pm 3.8$ years (range: $0.4-12.7$ years). Renal biopsy was performed on 12 patients and revealed focal segmental glomerulosclerosis in five patients, minimal change nephrotic syndrome in four patients, and mesangial proliferative glomerulonephritis in three patients. The other 23 patients did not consent to undergo renal biopsy. All 35 patients received prolonged steroid or immunosuppressive agent treatment. Eight patients did not respond to either steroids or immunosuppressive agents. One of these eight patients died from pneumonia with heart failure within seven weeks after disease onset. Twenty seven patients responded to either prolonged steroid therapy or immunosuppressive agents. During the follow-up period, two patients progressed to ESRD. One patient, who responded to cyclosporin A, progressed to ESRD within 71 months after disease onset; another patient, who showed no response to immunosuppressive agents, progressed to ESRD within 74 months after disease onset.

Patient 31 (Table 1) initially presented with eyelid edema at 4.2 years of age. Physical examination revealed eyelid edema and normal male external genitalia. Blood pressure was normal and a urine dipstick revealed 3+ albumin. His 24-h proteinuria was $4.8 \mathrm{~g}$ and serum albumin was $10.6 \mathrm{~g} / \mathrm{L}$. Serum cholesterol was $8.85 \mathrm{mM}$. He screened negative for Wilms' tumor by kidney ultrasound. He failed to respond to prednisone treatment $\left(2 \mathrm{mg}^{-1} \cdot \mathrm{kg}^{-1} \cdot 24 \mathrm{~h}^{-1}\right)$ over a 4-week course. However, after eight weeks of oral prednisone treatment, complete remission was achieved. A renal biopsy was refused by his parents, and he was diagnosed with isolated SRNS. Neither of his parents had proteinuria.

\section{Karyotype analysis or $\mathrm{Y}$ chromosome identification}

Karyotype analysis showed a 46, XY karyotype in five patients. SRY PCR analysis indicated the presence of a $Y$ chromosome in the remaining patients (Table 1).

\section{WT1 mutational analysis}

The WT1 variant, IVS4+14T>C, was identified in patient 31 (Figure 1) and was not observed in controls, indicating that it is a mutation of WT1. However, no WT1 mutations were found in the other 34 patients. We also identified one variant (5'-UTR-7G>T) in the 5'-untranslated region of WT1 in two patients and four controls, one silent mutation (126C>T) in exon 1 in 27 patients and 46 controls, one variant (IVS3+16G>A) in intron 3 in one patient and two controls, one silent mutation $(903 A>G)$ in exon 7 in 30 patients and 48 controls, and one variant (IVS7-32C $>A$ ) in intron 7 in three patients and two controls, indicating that these variants and silent mutations are WT1 polymorphisms (Table 2). 
Table 1. Clinical data for 35 boys with sporadic isolated steroid-resistant nephrotic syndrome.

\begin{tabular}{|c|c|c|c|c|c|c|c|}
\hline Patient & $\begin{array}{c}\text { Age of } \\
\text { onset } \\
\text { (years) }\end{array}$ & $\begin{array}{l}\text { Creatinine } \\
\quad(\mu \mathrm{M})\end{array}$ & BUN (mM) & $\begin{array}{l}\text { Renal } \\
\text { biopsy }\end{array}$ & $\begin{array}{c}\text { Karyotype/Y } \\
\text { chromosome } \\
\text { status }\end{array}$ & $\begin{array}{l}\text { Therapy and } \\
\text { response }\end{array}$ & $\begin{array}{c}\text { ESRD after } \\
\text { disease onset } \\
\text { (months) }\end{array}$ \\
\hline 1 & 12.2 & 74 & 10.9 & ND & $\mathrm{Y}^{\dagger}$ & GC, CTX, MMF (NR) & $\mathrm{N}$ \\
\hline 2 & 0.4 & 25 & 3.7 & FSGS & $Y^{\dagger}$ & GC (NR) & $\mathrm{N}$ \\
\hline 3 & 3.5 & 33 & 6.7 & FSGS & $Y^{\dagger}$ & $\mathrm{GC}, \mathrm{CsA}(\mathrm{R})$ & $\mathrm{N}$ \\
\hline 4 & 7.6 & 37 & 4.1 & FSGS & $Y^{\dagger}$ & GC, CsA (NR) & 74 \\
\hline 5 & 3.7 & 30 & 3.3 & MCNS & $Y^{\dagger}$ & $\mathrm{GC}(\mathrm{R})$ & $\mathrm{N}$ \\
\hline 6 & 0.7 & 74 & 1.4 & ND & $Y^{\dagger}$ & GC (NR) & $\mathrm{N}$ \\
\hline 7 & 4.6 & 41 & 4.2 & FSGS & $\mathrm{Y}^{\dagger}$ & $\mathrm{GC}, \mathrm{CsA}(\mathrm{R})$ & $\mathrm{N}$ \\
\hline 8 & 0.7 & 30 & 1.3 & ND & $46, X Y$ & GC, CTX (NR) & $\mathrm{N}$ \\
\hline 9 & 12.3 & 114 & 7.4 & MsPGN & $Y^{\dagger}$ & GC, CsA (R) & 71 \\
\hline 10 & 5.2 & 42 & 4.6 & ND & $Y^{\dagger}$ & $G C(R)$ & $\mathrm{N}$ \\
\hline 11 & 1.5 & 15.8 & 2.5 & ND & $Y^{\dagger}$ & GC, CsA (R) & $\mathrm{N}$ \\
\hline 12 & 1.3 & 56.3 & 6.9 & ND & $\mathrm{Y}^{\dagger}$ & GC, CsA (R) & $\mathrm{N}$ \\
\hline 13 & 6.5 & 40 & 5.8 & ND & $\mathrm{Y}^{\dagger}$ & $\mathrm{GC}(\mathrm{R})$ & $\mathrm{N}$ \\
\hline 14 & 2.6 & 29.7 & 1.6 & ND & $Y^{\dagger}$ & GC (R) & $\mathrm{N}$ \\
\hline 15 & 2.0 & 25 & 2.7 & $\mathrm{ND}$ & $Y^{\dagger}$ & $\mathrm{GC}(\mathrm{R})$ & $\mathrm{N}$ \\
\hline 16 & 0.8 & 26 & 4.8 & ND & $\mathrm{Y}^{\dagger}$ & GC, CsA (NR) & $\mathrm{N}$ \\
\hline 17 & 8.0 & 80 & 14.5 & MCNS & $\mathrm{Y}^{\dagger}$ & GC, CsA (NR) & $\mathrm{N}$ \\
\hline 18 & 5.4 & 14 & 3.0 & ND & $\mathrm{Y}^{\dagger}$ & $G C(R)$ & $\mathrm{N}$ \\
\hline 19 & 2.4 & 23 & 5.6 & ND & $\mathrm{Y}^{\dagger}$ & GC, CsA (R) & $\mathrm{N}$ \\
\hline 20 & 3.5 & 23 & 1.7 & ND & $Y^{\dagger}$ & GC, TG (NR) & $\mathrm{N}$ \\
\hline 21 & 1.8 & 30.6 & 4.9 & ND & $Y^{\dagger}$ & GC, CsA (R) & $\mathrm{N}$ \\
\hline 22 & 12.7 & 40 & 2.6 & MCNS & $\mathrm{Y}^{\dagger}$ & $\mathrm{GC}(\mathrm{R})$ & $\mathrm{N}$ \\
\hline 23 & 2.0 & 30.2 & 4.1 & ND & $\mathrm{Y}^{\dagger}$ & $\mathrm{GC}, \mathrm{CsA}(\mathrm{R})$ & $\mathrm{N}$ \\
\hline 24 & 5.8 & 47 & 7.6 & FSGS & $Y^{\dagger}$ & $\mathrm{GC}, \mathrm{TG}(\mathrm{R})$ & $\mathrm{N}$ \\
\hline 25 & 5.8 & 79 & 7.3 & MCNS & $\mathrm{Y}^{\dagger}$ & $\mathrm{GC}, \mathrm{CsA}(\mathrm{R})$ & $\mathrm{N}$ \\
\hline 26 & 4.8 & 22 & 7.0 & MsPGN & $\mathrm{Y}^{\dagger}$ & $\mathrm{GC}(\mathrm{R})$ & $\mathrm{N}$ \\
\hline 27 & 11.0 & 38 & 6.7 & MsPGN & $\mathrm{Y}^{\dagger}$ & GC, CsA (R) & $\mathrm{N}$ \\
\hline 28 & 2.6 & 42.3 & 2.7 & ND & $Y^{\dagger}$ & $G C(R)$ & $\mathrm{N}$ \\
\hline 29 & 2.1 & 29.9 & 4.3 & ND & $Y^{\dagger}$ & $G C(R)$ & $\mathrm{N}$ \\
\hline 30 & 1.7 & 20.2 & 4.7 & ND & $Y^{\dagger}$ & GC, CsA (R) & $\mathrm{N}$ \\
\hline 31 & 4.2 & 59 & 14.8 & ND & $\mathrm{Y}^{\dagger}$ & $\mathrm{GC}(\mathrm{R})$ & $\mathrm{N}$ \\
\hline 32 & 5.1 & 81.3 & 21.4 & ND & $46, X Y$ & GC, CsA (R) & $\mathrm{N}$ \\
\hline 33 & 1.2 & 10 & 4.0 & ND & $46, X Y$ & $\mathrm{GC}, \mathrm{CsA}(\mathrm{R})$ & $\mathrm{N}$ \\
\hline 34 & 1.6 & 23 & 4.9 & ND & $46, X Y$ & $\mathrm{GC}, \mathrm{CsA}(\mathrm{R})$ & $\mathrm{N}$ \\
\hline 35 & 1.8 & 27 & 3.7 & ND & $46, X Y$ & $\mathrm{GC}, \mathrm{CsA}(\mathrm{R})$ & $\mathrm{N}$ \\
\hline
\end{tabular}

BUN = serum urea nitrogen; ESRD = end-stage renal disease; ND = not determined; GC = glucocorticosteroid; CTX = cyclophosphamide; $\mathrm{MMF}=$ mycophenolate mofetil; $\mathrm{NR}=$ not in remission; $\mathrm{N}=$ not progressed to ESRD; FSGS = focal segmental glomerulosclerosis; $\mathrm{CsA}=$ cyclosporine; $\mathrm{R}=$ complete remission; $\mathrm{MCNS}=$ minimal change nephrotic syndrome; MsPGN = mesangial proliferative glomerulonephritis; TG = tripterygium glycosides. ${ }^{\top} S R Y$ PCR indicated presence of the $\mathrm{Y}$ chromosome. 


\section{T С T С TA T T C T С T C CA T T C

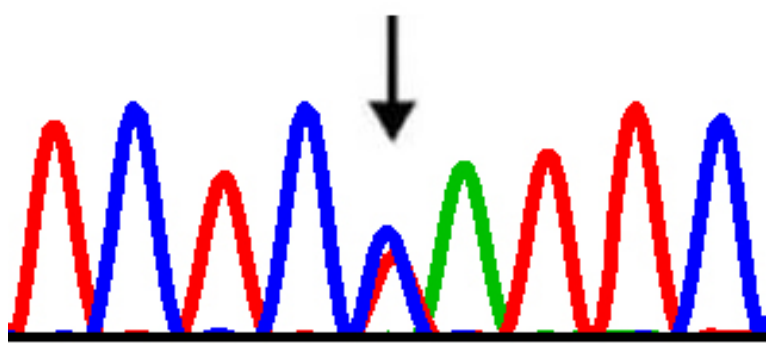

Figure 1. IVS4+14T >C mutation in intron 4 of WT1 was identified by sequencing. Arrow indicates mutant nucleotide.

Table 2. WT1 mutation and polymorphisms detected in 35 patients.

\begin{tabular}{|c|c|c|c|c|c|c|}
\hline Patient & $5^{\prime}-\mathrm{UTR}-7 \mathrm{G}>\mathrm{T}$ & $126 \mathrm{C}>\mathrm{T}(\mathrm{P} 42 \mathrm{P})$ & IVS3+16G $>A$ & IVS4+14T $>\mathrm{C}^{\dagger}$ & $903 \mathrm{~A}>\mathrm{G}(\mathrm{R} 300 \mathrm{R})$ & IVS7-32C $>\mathrm{A}$ \\
\hline 1 & & Hom & & & Hom & \\
\hline 2 & & Het & & & Hom & \\
\hline 3 & & Het & & & Het & \\
\hline 4 & & Hom & & & Hom & \\
\hline 5 & Het & Het & Het & & Het & Het \\
\hline 6 & & Het & & & Hom & \\
\hline 7 & & Hom & & & Hom & \\
\hline 8 & & Hom & & & Hom & \\
\hline 9 & & Het & & & Hom & \\
\hline 10 & & Het & & & Het & \\
\hline 11 & & Hom & & & Hom & \\
\hline 12 & & Het & & & Het & \\
\hline 13 & & Hom & & & Hom & \\
\hline 14 & & Het & & & Het & \\
\hline \multicolumn{7}{|l|}{15} \\
\hline 16 & & Hom & & & Hom & \\
\hline \multicolumn{7}{|l|}{17} \\
\hline \multicolumn{7}{|l|}{18} \\
\hline 19 & & Hom & & & Hom & \\
\hline 20 & & & & & Het & \\
\hline 21 & & Hom & & & Hom & \\
\hline 22 & & Het & & & Het & \\
\hline 23 & & & & & Het & \\
\hline 24 & & Hom & & & Hom & \\
\hline 25 & & Hom & & & Hom & \\
\hline \multicolumn{7}{|l|}{26} \\
\hline 27 & & Hom & & & Hom & \\
\hline 28 & & Het & & & Het & \\
\hline 29 & & & & & & Het \\
\hline 30 & & Hom & & & Hom & \\
\hline 31 & Het & Het & & Het & Het & Het \\
\hline 32 & & Hom & & & Hom & \\
\hline 33 & & & & & Het & \\
\hline 34 & & Het & & & Het & \\
\hline 35 & & Het & & & Het & \\
\hline
\end{tabular}

Hom = homozygous variant; Het $=$ heterozygous variant. ${ }^{\dagger}$ Novel mutation. 


\section{Splice site prediction}

IVS4+14T >C was not predicted to affect splicing using prediction algorithms hosted by the NetGene2 Server and the Berkley Drosophila Genome Project.

\section{DISCUSSION}

In this study, using direct sequencing, we detected no causative mutations in any of the 10 exons of WT1 in 35 boys with sporadic isolated SRNS. Our results suggest that routine mutation analysis of WT1 should not be recommended for boys with sporadic isolated SRNS.

We identified the WT1 variant, IVS4+14T>C, in one patient (patient 31). This variant was absent in the controls, indicating that it is a WT1 mutation; however, it was not predicted to affect splicing. This patient presented with SRNS at 4.2 years. He had a normal male phenotype and a $Y$ chromosome. No tumor was identified using renal ultrasound and he was, therefore, diagnosed with isolated SRNS. However, after 8 weeks of oral prednisone treatment, complete remission was achieved. It is possible that a subset of SRNS with a response to immunosuppressive agents has an underlying immune defect (Benoit et al., 2010). Therefore, we do not consider IVS4+14T $>C$ to be a causative mutation of SRNS.

We also detected five other WT1 variants, 5'-UTR-7G>T, 126C>T, IVS3+16G>A, 903A>G, and IVS7-32C>A in some patients and controls and believe them to be WT1 polymorphisms. All of these WT1 polymorphisms were identified in our previous study, which showed that there was no association between the five WT1 polymorphisms and SRNS in Chinese children (Wang et al., 2009).

No mutations in the WT1 gene have been identified in boys with sporadic isolated SRNS (Table 3) (Ruf et al., 2004b; Aucella et al., 2006; Mucha et al., 2006; Cho et al., 2008; Li et al., 2010). Mucha et al. (2006) screened a worldwide cohort (Central European, Turkish, African-American, Hispanic, or Asian backgrounds) of 84 boys with sporadic isolated SRNS for mutations in all 10 exons of WT1. No WT1 mutations were identified in these patients. They used multiplex capillary heteroduplex analysis, the sensitivity of which was $91 \%$, and direct sequencing. Li et al. (2010) screened 43 boys with sporadic isolated SRNS for mutations in exons 8 and 9 of WT1, but no mutations were found. Ruf et al. (2004b) examined 57 boys with sporadic isolated SRNS originating from Central Europe, Turkey, or India for mutations in exons 6-9 of WT1. They were unable to identify WT1 mutations in any of these patients. Aucella et al. (2006) performed mutation analysis of exons 8 and 9 of WT1 in 32 Italian boys with sporadic isolated SRNS, and no WT1 mutations were found in these patients. Cho et al. (2008) examined exons 8 and 9 of WT1 in 30 Korean boys with sporadic isolated SRNS and identified no mutations.

Table 3. Summary of detection rates of WT1 mutations in boys with sporadic isolated SRNS

\begin{tabular}{l|c|c|l|l|l}
\hline $\begin{array}{l}\text { Ethnic } \\
\text { background }\end{array}$ & $\begin{array}{c}\text { Number of } \\
\text { patients }\end{array}$ & $\begin{array}{c}\text { Detection rate of WT1 } \\
\text { mutations }\end{array}$ & Exons & Mutation detection method & References \\
\hline Worldwide cohort & 57 & $0 \%(0 / 57)$ & Exons 6-9 & $\begin{array}{l}\text { DHPLC and direct } \\
\text { sequencing }\end{array}$ & Ruf et al. (2004b) \\
\hline Worldwide cohort & 84 & $0 \%(0 / 84)$ & All 10 exons & MCHA and direct sequencing & Mucha et al. (2006) \\
\hline Italian & 32 & $0 \%(0 / 32)$ & Exons 8 and 9 & $\begin{array}{l}\text { DHPLC and direct } \\
\text { sequencing }\end{array}$ & Aucella et al. (2006) \\
\hline Korean & 30 & $0 \%(0 / 30)$ & Exons 8 and 9 & Direct sequencing & Cho et al. (2008) \\
\hline Chinese & 43 & $0 \%(0 / 43)$ & Exons 8 and 9 & Direct sequencing & Li et al. (2010) \\
\hline Chinese & 35 & $0 \%(0 / 35)$ & All 10 exons & Direct sequencing & This study \\
\hline
\end{tabular}

SRNS = steroid-resistant nephrotic syndrome; DHPLC = denaturing high-performance liquid chromatography; MCHA $=$ multiplex capillary heteroduplex analysis. 
Four boys with isolated nephrotic syndrome have been reported to carry WT1 mutations. Takata et al. (2000) reported a boy with nephropathy without genital abnormalities or Wilms' tumor caused by the WT1 mutation R312Q in exon 7. His age of onset was 2 years, and he rapidly progressed to ESRD. His karyotype was 46, XY. Tajima et al. (2003) reported a boy with focal segmental glomerulosclerosis without genital abnormalities or Wilms' tumor caused by the WT1 mutation IVS9 $+5 \mathrm{G}<\mathrm{A}$. His age of onset was 5 years, and at 8 years of age, his serum creatinine level was $0.8 \mathrm{mg} / \mathrm{dL}$. Chernin et al. (2010) reported a boy with isolated nephrotic syndrome caused by the WT1 mutation R394W in exon 9 . His age of onset was 1.5 years and he progressed rapidly to ESRD by the age of 1.7 years. His karyotype was $46, \mathrm{XY}$. Recently, we reported a 6.3-year-old boy with isolated nephrotic syndrome caused by the WT1 mutation K351E in exon 8. He rapidly progressed to ESRD and his karyotype was 46, XY (Yang et al., 2013a).

In conclusion, no causative mutations were identified in any of the 10 exons of WT1 in 35 boys with sporadic isolated SRNS. Our results suggest that mutation analysis of WT1 should not be routinely recommended for boys with sporadic isolated SRNS.

\section{Conflicts of interest}

The authors declare no conflicts of interest.

\section{ACKNOWLEDGMENTS}

Research supported by grants from the National Nature Science Foundation of China (\#81270766), the Key Project of Social Development of Fujian Province of China (\#2013Y0072), the Major Project of Nanjing Military Command (\#14ZX27), and the Nature Science Foundation of Fujian Province of China (\#2015J01407).

\section{REFERENCES}

Aucella F, Bisceglia L, De Bonis P, Gigante M, et al. (2006). WT1 mutations in nephrotic syndrome revisited. High prevalence in young girls, associations and renal phenotypes. Pediatr. Nephrol. 21: 1393-1398. http://dx.doi.org/10.1007/s00467$\underline{006-0225-0}$

Barbaux S, Niaudet P, Gubler MC, Grünfeld JP, et al. (1997). Donor splice-site mutations in WT1 are responsible for Frasier syndrome. Nat. Genet. 17: 467-470. http://dx.doi.org/10.1038/ng1297-467

Benoit G, Machuca E and Antignac C (2010). Hereditary nephrotic syndrome: a systematic approach for genetic testing and a review of associated podocyte gene mutations. Pediatr. Nephrol. 25: 1621-1632. http://dx.doi.org/10.1007/s00467-010$\underline{1495-0}$

Bruening W, Bardeesy N, Silverman BL, Cohn RA, et al. (1992). Germline intronic and exonic mutations in the Wilms' tumour gene (WT1) affecting urogenital development. Nat. Genet. 1: 144-148. http://dx.doi.org/10.1038/ng0592-144

Call KM, Glaser T, Ito CY, Buckler AJ, et al. (1990). Isolation and characterization of a zinc finger polypeptide gene at the human chromosome 11 Wilms' tumor locus. Cell 60: 509-520. http://dx.doi.org/10.1016/0092-8674(90)90601-A

Chernin G, Vega-Warner V, Schoeb DS, Heeringa SF, et al.; Members of the GPN Study Group (2010). Genotype/phenotype correlation in nephrotic syndrome caused by WT1 mutations. Clin. J. Am. Soc. Nephrol. 5: 1655-1662. http://dx.doi. org/10.2215/CJN.09351209

Cho HY, Lee JH, Choi HJ, Lee BH, et al. (2008). WT1 and NPHS2 mutations in Korean children with steroid-resistant nephrotic syndrome. Pediatr. Nephrol. 23: 63-70. http://dx.doi.org/10.1007/s00467-007-0620-1

Haber DA, Sohn RL, Buckler AJ, Pelletier J, et al. (1991). Alternative splicing and genomic structure of the Wilms tumor gene WT1. Proc. Natl. Acad. Sci. USA 88: 9618-9622. http://dx.doi.org/10.1073/pnas.88.21.9618

Harley VR, Clarkson MJ and Argentaro A (2003). The molecular action and regulation of the testis-determining factors, SRY (sex-determining region on the Y chromosome) and SOX9 [SRY-related high-mobility group (HMG) box 9]. Endocr. Rev. 24: 466-487. http://dx.doi.org/10.1210/er.2002-0025 
Li J, Ding J, Zhao D, Yu Z, et al. (2010). WT1 gene mutations in Chinese children with early onset nephrotic syndrome. Pediatr. Res. 68: 155-158. http://dx.doi.org/10.1203/PDR.0b013e3181e4c9e3

Löwik MM, Groenen PJ, Pronk I, Lilien MR, et al. (2007). Focal segmental glomerulosclerosis in a patient homozygous for a CD2AP mutation. Kidney Int. 72: 1198-1203. http://dx.doi.org/10.1038/sj.ki.5002469

Mucha B, Ozaltin F, Hinkes BG, Hasselbacher K, et al.; Members of the APN Study Group (2006). Mutations in the Wilms' tumor 1 gene cause isolated steroid resistant nephrotic syndrome and occur in exons 8 and 9. Pediatr. Res. 59: 325-331. http://dx.doi.org/10.1203/01.pdr.0000196717.94518.f0

Niaudet P and Gubler MC (2006). WT1 and glomerular diseases. Pediatr. Nephrol. 21: 1653-1660. http://dx.doi.org/10.1007/ s00467-006-0208-1

Pelletier J, Bruening W, Kashtan CE, Mauer SM, et al. (1991). Germline mutations in the Wilms' tumor suppressor gene are associated with abnormal urogenital development in Denys-Drash syndrome. Cell 67: 437-447. http://dx.doi. org/10.1016/0092-8674(91)90194-4

Philippe A, Nevo F, Esquivel EL, Reklaityte D, et al. (2008). Nephrin mutations can cause childhood-onset steroid-resistant nephrotic syndrome. J. Am. Soc. Nephrol. 19: 1871-1878. http://dx.doi.org/10.1681/ASN.2008010059

Ruf RG, Lichtenberger A, Karle SM, Haas JP, et al. (2004a). Patients with mutations in NPHS2 (podocin) do not respond to standard steroid treatment of nephrotic syndrome. J. Am. Soc. Nephrol. 15: 722-732. http://dx.doi.org/10.1097/01. ASN.0000113552.59155.72

Ruf RG, Schultheiss M, Lichtenberger A, Karle SM, et al. (2004b). Prevalence of WT1 mutations in a large cohort of patients with steroid-resistant and steroid-sensitive nephrotic syndrome. Kidney Int. 66: 564-570. http://dx.doi.org/10.1111/j.15231755.2004.00775.x

Tajima T, Sasaki S, Tanaka Y, Kusunoki H, et al. (2003). 46,XY phenotypic male with focal segmental glomerulosclerosis caused by the WT1 splice site mutation. Horm. Res. 60: 302-305. http://dx.doi.org/10.1159/000074249

Takata A, Kikuchi H, Fukuzawa R, Ito S, et al. (2000). Constitutional WT1 correlate with clinical features in children with progressive nephropathy. J. Med. Genet. 37: 698-701. http://dx.doi.org/10.1136/jmg.37.9.698

Tu XO, Lan FU and Zhu ZO (2008). Positioning analysis of the Yq11 deletion in a patient with azoospermia. Zhonghua Yi Xue Yi Chuan Xue Za Zhi 25: 203-205.

Wang JJ, Fu R and Ye LY (2009). Genetic variations of NPHS2 and WT1 genes in 15 Chinese children with sporadic steroidresistant nephrotic syndrome. Zhonghua Er Ke Za Zhi 47: 221-223.

Weber S, Gribouval O, Esquivel EL, Morinière V, et al. (2004). NPHS2 mutation analysis shows genetic heterogeneity of steroid-resistant nephrotic syndrome and low post-transplant recurrence. Kidney Int. 66: 571-579. http://dx.doi. org/10.1111/j.1523-1755.2004.00776.x

Yang Y, Feng D, Huang J, Nie X, et al. (2013a). A child with isolated nephrotic syndrome and WT1 mutation presenting as a 46, XY phenotypic male. Eur. J. Pediatr. 172: 127-129. http://dx.doi.org/10.1007/s00431-012-1770-0

Yang YH, Zhao F, Feng DN, Wang JJ, et al. (2013b). Wilms' tumor suppressor gene mutations in girls with sporadic isolated steroid-resistant nephrotic syndrome. Genet. Mol. Res. 12: 6184-6191. http://dx.doi.org/10.4238/2013.December.4.5

Yu Z, Ding J, Huang J, Yao Y, et al. (2005). Mutations in NPHS2 in sporadic steroid-resistant nephrotic syndrome in Chinese children. Nephrol. Dial. Transplant. 20: 902-908. http://dx.doi.org/10.1093/ndt/gfh769 